\title{
Numerical investigation of a novel burner to combust anode exhaust gases of SOFC stacks
}

\author{
Paulina Pianko-Oprych*, Zdzisław Jaworski \\ West Pomeranian University of Technology, Szczecin, Institute of Chemical Engineering and Environmental Protection \\ Processes, Faculty of Chemical Technology and Engineering, al. Piastów 42, 71-065 Szczecin, Poland \\ "Corresponding author: e-mail: paulina.pianko@zut.edu.pl
}

\begin{abstract}
The aim of the present study was a numerical investigation of the efficiency of the combustion process of a novel concept burner under different operating conditions. The design of the burner was a part of the development process of a complete SOFC based system and a challenging combination of technical requirements to be fulfilled. A Computational Fluid Dynamics model of a non-premixed burner was used to simulate combustion of exhaust gases from the anode region of Solid Oxide Fuel Cell stacks. The species concentrations of the exhaust gases were compared with experimental data and a satisfactory agreement of the conversion of hydrocarbons was obtained. This validates the numerical methodology and also proves applicability of the developed approach that quantitatively characterized the interaction between the exhaust gases and burner geometry for proper combustion modelling. Thus, the proposed CFD approach can be safely used for further numerical optimisation of the burner design.
\end{abstract}

Keywords: burner, non-premixed combustion, CFD, geometry optimisation.

\section{INTRODUCTION}

An increase in global energy demand, depletion of fossil fuels and increased concerns over the impact of the greenhouse gases on global warming led to the development of alternative fuels and energy systems. One of the most interesting technology for useful energy production is a Combined Heat and Power (CHP) system based on Solid Oxide Fuel Cells (SOFCs). SOFC based systems have received significant attention since they reduce the dependency on fossil fuel resources and decrease the gas emissions to the atmosphere, and in addition they have high electrical efficiency (40-60\%) as well as provide energy security and independence ${ }^{1}$. A typical SOFC power system consists of a fuel reformer, air heat exchanger, fuel cell stack and burner. The burners used in the SOFC power plants, in contradiction to the conventional combustion systems, have a number of significant advantages including limited release of harmful emissions to the environment, high combustion stability, possibility of recovery of unspent energy from the gases exiting the SOFC stacks and also improvement of the overall efficiency of the SOFC based system. Chan et al. $^{2}$ presented two simple SOFC power systems fed by hydrogen and methane, respectively, in which the waste heat was recovered by an afterburner and used to preheat the fuel and air prior to their inlets into the SOFC. The results revealed that the addition of the afterburner to the SOFC system increased the overall efficiency of the system by around $70 \%{ }^{2}$. Fontell et al. ${ }^{3}$ showed that a catalytic burner used in a $1-5 \mathrm{~kW}$ SOFC system can efficiently reduce the harmful emissions for various fuel compositions by maintaining the flue gas temperature at around $700^{\circ} \mathrm{C}$. Another example of the improvement in the overall efficiency of a $2 \mathrm{~kW}$ SOFC system by using an afterburner was presented by Hong et al. ${ }^{4}$. In the system the hot flue gas exiting the afterburner was passed through a heat exchanger, where it preheats the air prior to entering the SOFC. Continued experimental investigations by Yen et al. ${ }^{5}$ showed that an optimal afterburner operation was obtained by assum- ing in the SOFC system the anode off gas temperature of $650^{\circ} \mathrm{C}$, cathode off gas temperature of $390^{\circ} \mathrm{C}$, flame barrier temperature of $700^{\circ} \mathrm{C}$ and an excess air ratio of 2.0 at fuel utilization of 0.6 . Under these conditions the afterburner operated in a long term continuous manner without the need for either cooling air or any additional fuel other than that provided by the anode off gas. Yu et al. ${ }^{6}$ performed a study of a catalytic burner for a power generating system with high temperature stationary fuel cells. They investigated three commercially available catalysts. Flow and combustion characteristics of the fuel cell power system were analysed in terms of performance and stability over various operating parameters. It was found that catalytic combustion was a promising alternative to homogenous combustion since the former has total oxidation capability of low calorific value gases at low temperatures.

The experimental results ${ }^{2-6}$ gave insight into the combustion phenomenon within porous burner. However, the complexity of burners and strict requirements for process controlling required support of the burner development by numerical investigations. The modelling should mainly aim at avoiding excessively high temperature values and temperature gradients, which could affect the stability of porous burners. An extensive CFD study on the burner design was carried out by Zadghaffari et al. ${ }^{7}$, who tested different angles of gas injection to optimize the burner performance and decrease the pollutant emission. A 3D turbulent flow model was applied for the non-premixed burner and four different injection topologies were reported. The optimal performance with respect to uniform temperature distribution and low pollutant emission was achieved when the gas injection angles were equal to $30^{\circ}, 45^{\circ}$ or $60^{\circ}$. For $80^{\circ}$ angle the flame was produced far from the burner tip and unacceptable temperature distribution and high content of pollutants was achieved. The maximum temperature was found at the flame center and then temperature gradually reduced radially and axially in the outward direction. With a support of numerical investigations, a new two-stage diffusion type burner was developed for the conversion of the anode 
off gas from the SOFC stack, within the framework of the EU collaborative project "FC-DISTRICT" . The adiabatic flame temperatures were computed with the software package CHEMKIN Reaction Design 4.1.1 using the chemical and phase equilibrium calculation. As a result of numerical investigations, the necessity of splitting the total cathode air stream was identified. Computational Fluid Dynamics simulations were also used to predict the burner orifice turbulent flow by Reis at el. ${ }^{9}$. Four different turbulence models: the standard, RNG, realizable k- $\varepsilon$ and Reynolds Stress Model (RSM) were used to estimate pressure drop, velocity profiles and orifice discharge coefficient. It was noticed that the realizable k- $\varepsilon$ model was the most appropriate turbulence model to be used for the considered application. In addition, three different burner heat load conditions were analysed. The predicted temperatures were higher than experimental ones, but the differences were acceptable. It was also found that the simulated flame was very similar to the real one, however a picture of the entire flame was not shown'. Nevertheless, the 3D simulations were concluded as an effective tool to design burner nozzles and to provide valuable recommendations.

A similar study of the flow field in a swirl regeneration burner was presented by $\mathrm{Fu}$ et al. ${ }^{10}$. It was shown that at the sudden expansion zones and the near wall region the flow characteristics and back flow features of the realizable $\mathrm{k}-\varepsilon$ model were clearer than those of the standard k- $\varepsilon$ model and the RNG k- $\varepsilon$ model. However, better back flow characteristics and more abundant details of flow field were obtained using the SST $k-\omega$ model for which the centre average velocity as well as pressure at the inlet and outlet agreed well with experiments. Hence, it can be concluded that the developed models helped not only to understand the complex interactions between reactive flow, but also to explore burner conditions, which were beyond available experimental facilities.

It has to be underlined that a critical issue in the burner development is ensuring stable conversion of the low calorific value of the anode off gases during the steady state system operation as well as of the high calorific value reformate gas during the system operations of start-up or shut-down. Therefore, the aim of this study was to analyse the operating cycle of the modelled burner through three distinct phases: (i) phase I - heating up period of the start-up burner operation with natural gas and cathode off gas streams, (ii) phase II - transition from the start-up burner operation to that with anode off gas, natural gas and cathode off gas at 47 and 100\% loads, (iii) phase III - long term (afterburner only) operation assuming the anode off gas and cathode off gas streams.

\section{Numerical model}

A schematic of the non-premixed burner design proposed by sunfire ${ }^{11}$ is shown in Figure 1. The burner consisted of three independent inlets of an anode off gas, cathode off gas and natural gas, respectively, located at the upper part of the burner. In the down part of the burner an exhaust gas outlet was located.

The main upper part of the burner contained the anode off gas and cathode off gas chambers. Streams of the anode off gas (Fig. 2a) and cathode off gas (Fig. 2b)

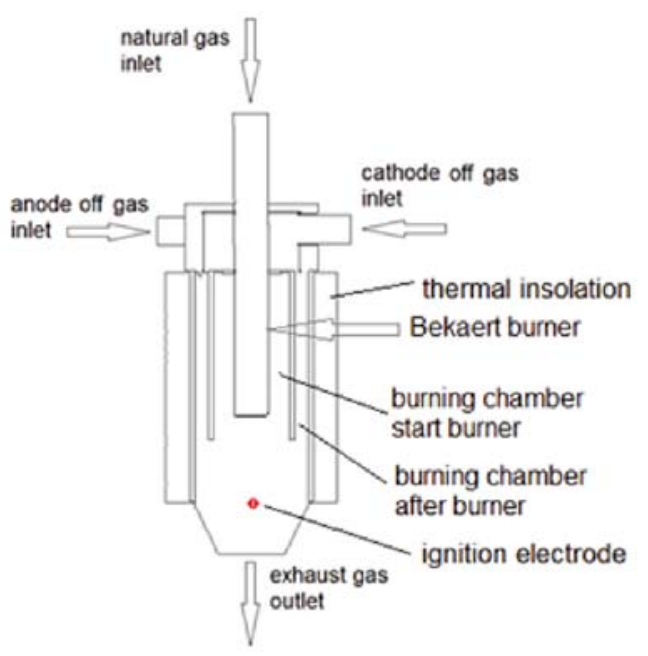

Figure 1. A schematic of the burner geometry

are directed into the main combustion zone located in the center lower part of the burner. The cathode off gas provided enough oxygen, which in combination with the natural gas (Fig. 2c) injected into the porous Bekaert burner by the central inlet pipe, produced gasfuel mixture that was ignited by the ignition electrode in the main combustion area. In order to achieve the purpose of ignition stability, the expansion structure of the burner was adopted in the lower part of the burner. Experimental burner walls were made from stainless steel, while the internal burner was from Alotec ${ }^{\circledR}$ ceramic. Material properties for the burner are shown in Table 1.

An unstructured tetrahedral mesh was generated with a grid size of 1.7 million of computational cells. The mesh surrounding the inlet surfaces was assumed finer in order to consider larger gradients of variables expected in these regions. The computational mesh is presented in Figure 3.

The fluid zone for Bekaert wall region was $2 \mathrm{~mm}$ thick and its open porosity was equal to 0.5 , while the interior zone of Bekaert burner was modeled assuming a porous jump boundary conditions with the face permeability equal to $1 \cdot 10^{10}$ and pressure jump coefficient of 1.0.

Numerical simulations of the novel burner design to combust exhaust gases from SOFC stack anodes were
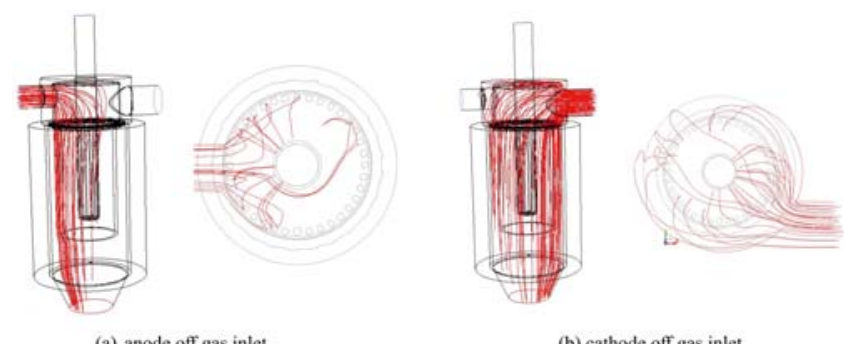

(a) anode off gas inlet (b) cathode off gas inlet

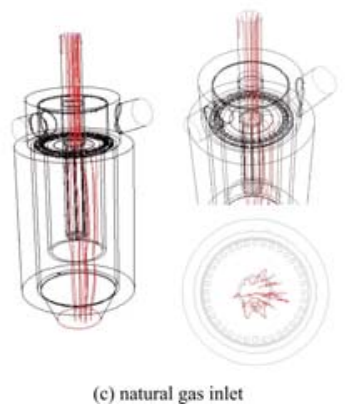

Figure 2. Distributions of streamlines from: (a) anode off gas inlet, (b) cathode off gas inlet, (c) natural gas inlet 
performed using the commercial CFD code ANSYS Fluent 15.0 based on the RANS approach with full 3D geometry. In the combustion modelling the non-premixed model was used for non-adiabatic conditions (Eqs. (4-5)). The model considers fast burning with the overall rate of reaction controlled by the k- $\varepsilon$ turbulence model with standard parameters and turbulent intensity for inlets equal to $10 \%$ (Eqs. (6-7)) together with mass, momentum and energy balances, Eqs. (1-3), respectively. Radiative heat transfer was accounted for by using the Discrete Ordinates (DO) method (Eq. (8)). The gas mixture density was estimated from the PDF model and its heat capacity from the mixing law. A PDF table was built to include thermochemistry aspects and their interaction with turbulence. The PDF mixture was initialized with a WSGGM (Weighted-Sum-of-Gray-Gases-Model) based on absorption coefficient. The governing equations for the burner processes are presented in Table 2.

The combustion process was modelled within the burner volume without accounting for the Bekaert burner geometry in order to simplify the already complex mesh. The presence of the Bekaert burner was modeled by including its wall with open slots in the burner geometry. In addition, to mimic real working burner conditions an electrode was introduced into the geometry within the Alotec cylinder geometry. The initial temperature of the electrode was assumed at $1000[\mathrm{~K}]$. The cathode off gas was treated as an oxidizer and was introduced through the inlet located at the right side as shown in Figure 1. The anode off gas introduced to the burner by the inlet surface located at the left side was assumed as primary fuel component, while natural gas was introduced from the top part of the burner and treated as a secondary flow. The mean species mixture fraction for fuel was equal to 1 , while for oxidizer it was equal to 0 . The pressure-velocity coupling PRESTO was used for pressure term discretization. Table 3 presents the combustion

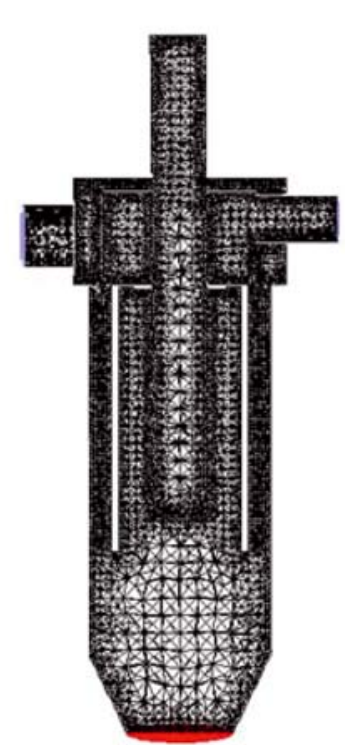

Figure 3. View of the cross section of the numerical mesh for tested burner

reactions of the anode exhaust gases from SOFC stacks with the kinetics constants included in the simulations.

The major challenge for the burner development results from analysis of the different operation modes starting from a heating up period of the burner start-up operation based on streams of natural gas and the cathode off gas (case I) through normal operation of start-up and after burning at $47 \%$ and $100 \%$ loads (case II) and ending with after burning operation assuming only the cathode off gas and anode off gas streams flow through the external ring (section A) (case III).

In the case I the cathode off gas flows through the external ring at flow rates varying in the range of 600 to $800[\mathrm{Nl} / \mathrm{min}]$ at temperature of 25,400 and $800\left[{ }^{\circ} \mathrm{C}\right]$, while in the case II a simultaneous operation of start-up and after burning based on case I was considered including additional anode off gas stream flowing in the

Table 1. Material properties for the burner

\begin{tabular}{|l|c|c|c|}
\hline \multicolumn{1}{|c|}{ Material } & $\begin{array}{c}\text { Density } \\
{\left[\mathrm{kg} / \mathrm{m}^{3}\right]}\end{array}$ & Specific heat $[\mathrm{J} /(\mathrm{kgK})]$ & $\begin{array}{c}\text { Thermal conductivity } \\
{[\mathrm{W} / \mathrm{mK}]}\end{array}$ \\
\hline Stainless steel & 7900 & 450 & 11.3 \\
\hline Alotec ceramic & 3870 & 995 & 27 \\
\hline
\end{tabular}

Table 2. The governing equations for the burner

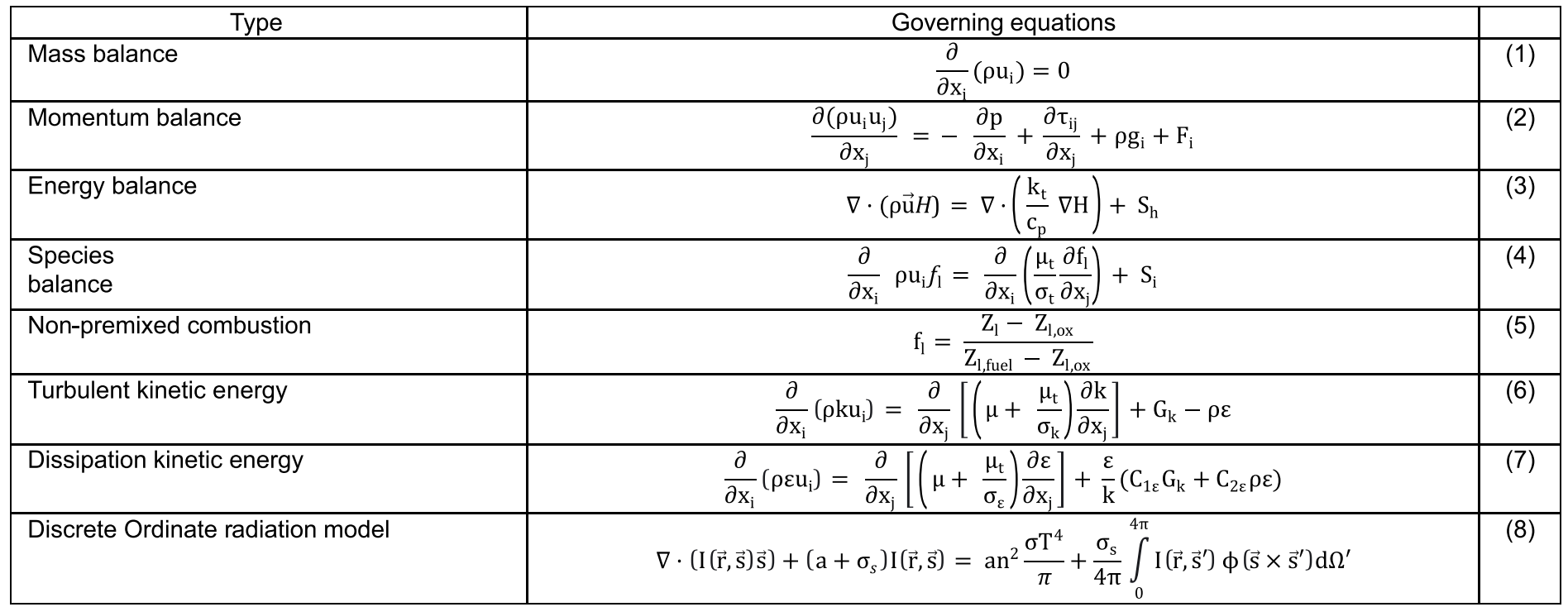


external ring at two different loads. Flow and temperature data of the analysed combustion cases are presented in Table 4. Table 5 presents initial species concentrations for $47 \%$ and $100 \%$ loads used in the CFD simulations.

The aim of the study was to understand the main factors, which influence the efficiency of the burner, temperature distributions in the burner and predict the combustion parameters under different operating conditions.

\section{RESULTS AND DISCUSSION}

This section presents and analyses the CFD results obtained for the novel burner design performance dedicated to a CHP (Combined Heat and Power generation system) system based on the SOFC stacks. Three different cases were considered for the burner.

In the case I, the start-up operation was analysed in the burner assuming only the feeding flows of the cathode off gas and a mixture of the natural gas with air. The velocity distributions inside the burner at the inlet of the natural gas with air are shown in Figure 4. The flow entered the anode off gas chamber only through the circular holes between the anode off gas chamber and the main combustion zone.

In the case II, a simultaneous operation of start-up and after burner operation with natural gas with air, anode off gas and cathode off gas were modelled inside the burner with initial load conditions of 47 and $100 \%$. From the performed CFD simulations it was observed that the flows enter the combustion zone from the anode and cathode off gas chamber towards the burner outlet and effectively mix within the combustion zone. Hot spots shown in Figure 5 were located between the Bekaert burner and the Alotec cylinder with a maximum temperature equal to $1600[\mathrm{~K}]$, while the average temperature at the outlet of the burner was equal to 1116.8 [K].

The accuracy of the CFD predictions for the burner was tested based on the results obtained for the case III of after burner operation only for the cathode off gas and anode off gas flow through the external ring. It was thus possible to access to the measurement data [11] for that specific case allowed checking and improving the results. The swirling flow velocity was linearized when entering the combustion zone from the anode and cathode off gas chamber, as it can be noticed in Figure 6 . The computed velocity at the outlet of the burner for the $47 \%$ load condition was equal to $5.24 \mathrm{~m} / \mathrm{s}$, while for the $100 \%$ load it was $15.05 \mathrm{~m} / \mathrm{s}$.

For the $47 \%$ load conditions the simulated average temperature at the burner outlet was equal to $1098\left[{ }^{\circ} \mathrm{C}\right]$, while the experimental one was reported as $1050\left[{ }^{\circ} \mathrm{C}\right]$. For the $100 \%$ load the CFD temperature was $1057\left[{ }^{\circ} \mathrm{C}\right]$ and the experimental one $\left.1023\left[{ }^{\circ} \mathrm{C}\right]\right]$, as shown in Fig. 7. One can conclude a very good agreement between the predicted and experimental values [11] of temperature was obtained. In addition, a significant reduction in species mole fractions was noticed at the burner outlet as it can be seen in Tables 6 and 7, respectively. Relative differences between numerical results and experimental data [11] are the highest for hydrocarbons, however it should be underlined that their amount was a trace in the order of $1 \mathrm{E}-15$. The anode off gas and cathode off gas were

Table 3. Global species reactions with their kinetics parameters

\begin{tabular}{|c|c|c|c|}
\hline Reactions & $\begin{array}{c}\text { Pre-exponential factor } \\
{\left[\mathrm{kmol} / \mathrm{m}^{3} \mathrm{~s}\right]}\end{array}$ & $\begin{array}{c}\text { Activation energy } \\
{[\mathrm{J} / \mathrm{kmol}]}\end{array}$ & $1.255 \cdot 10^{8}$ \\
\hline $\mathrm{CH}_{4}+0.5 \mathrm{O}_{2} \rightarrow \mathrm{CO}+2 \mathrm{H}_{2}$ & $4.4 \cdot 10^{11}$ & $1.703 \cdot 10^{8}$ & $(10)$ \\
\hline $\mathrm{CO}+0.5 \mathrm{O}_{2} \rightarrow \mathrm{CO}_{2}$ & $2.24 \cdot 10^{12}$ & $1.46 \cdot 10^{8}$ & $(11)$ \\
\hline $\mathrm{H}_{2}+0.5 \mathrm{O}_{2} \rightarrow \mathrm{H}_{2} \mathrm{O}$ & $5.69 \cdot 10^{11}$ & $1.256 \cdot 10^{8}$ & $(12)$ \\
\hline $\mathrm{C}_{2} \mathrm{H}_{6}+3.5 \mathrm{O}_{2} \rightarrow 2 \mathrm{CO}_{2}+3 \mathrm{H}_{2} \mathrm{O}$ & $6.186 \cdot 10^{9}$ & $1.256 \cdot 10^{8}$ & $(13)$ \\
\hline $\mathrm{C}_{3} \mathrm{H}_{8}+5 \mathrm{O}_{2} \rightarrow 3 \mathrm{CO}_{2}+4 \mathrm{H}_{2} \mathrm{O}$ & $6.186 \cdot 10^{9}$ & $1.25)$ \\
\hline
\end{tabular}

Table 4. Inputs parameters for analysed combustion cases

\begin{tabular}{|c|c|c|c|c|c|c|c|c|c|}
\hline \multirow[b]{2}{*}{ Case } & \multicolumn{3}{|c|}{$\begin{array}{l}\text { Velocity inlet } \\
\text { at } 47 \% \text { load }\end{array}$} & \multicolumn{3}{|c|}{$\begin{array}{l}\text { Velocity inlet } \\
\text { at } 100 \% \text { load }\end{array}$} & \multicolumn{3}{|c|}{$\begin{array}{c}\text { Inlet } \\
\text { temperature }\end{array}$} \\
\hline & $\begin{array}{c}\text { anode off } \\
\text { gas } \\
{[\mathrm{m} / \mathrm{s}]}\end{array}$ & $\begin{array}{c}\text { cathode } \\
\text { off gas } \\
{[\mathrm{m} / \mathrm{s}]}\end{array}$ & $\begin{array}{c}\text { natural } \\
\text { gas + air } \\
{[\mathrm{m} / \mathrm{s}]}\end{array}$ & $\begin{array}{c}\text { anode off } \\
\text { gas } \\
{[\mathrm{m} / \mathrm{s}]}\end{array}$ & $\begin{array}{c}\text { cathode off } \\
\text { gas } \\
{[\mathrm{m} / \mathrm{s}]}\end{array}$ & $\begin{array}{c}\text { natural } \\
\text { gas + air } \\
{[\mathrm{m} / \mathrm{s}]}\end{array}$ & $\begin{array}{c}\text { anode } \\
\text { off } \\
{\left[{ }^{\circ} \mathrm{C}\right]}\end{array}$ & $\begin{array}{c}\text { cathode } \\
\text { off gas } \\
{\left[{ }^{\circ} \mathrm{C}\right]}\end{array}$ & $\begin{array}{c}\mathrm{NG}+\text { air } \\
{\left[{ }^{\circ} \mathrm{C}\right]}\end{array}$ \\
\hline Case I & - & 7.524 & 3.929 & - & 21.159 & 3.929 & - & 830 & 25 \\
\hline Case II & 4.173 & 7.524 & 3.929 & 9.831 & 18.958 & 12.69 & 830 & 830 & 25 \\
\hline Case III & 4.173 & 7.524 & - & 9.831 & 18.958 & - & 830 & 830 & - \\
\hline
\end{tabular}

Table 5. Initial species concentrations for $47 \%$ and $100 \%$ load

\begin{tabular}{|c|l|l|l|l|c|c|}
\hline \multirow{3}{*}{ Species } & \multicolumn{5}{|c|}{ Mole fractions [mole/mole] } \\
\cline { 2 - 7 } & \multicolumn{3}{|c|}{$47 \%$ load } & \multicolumn{4}{c|}{$100 \%$ load } \\
\cline { 2 - 7 } & anode off gas & $\begin{array}{c}\text { cathode off } \\
\text { gas }\end{array}$ & natural gas & anode off gas & $\begin{array}{c}\text { cathode off } \\
\text { gas }\end{array}$ & natural gas \\
\hline $\mathrm{CH}_{4}$ & 0.00034 & 0 & 0.0605 & 0.00034 & 0 & 0.0605 \\
\hline $\mathrm{C}_{2} \mathrm{H}_{6}$ & $1.26 \cdot 10^{-10}$ & 0 & 0.0003 & $1.26 \cdot 10^{-10}$ & 0 & 0.0003 \\
\hline $\mathrm{C}_{3} \mathrm{H}_{8}$ & $2.02 \cdot 10^{-15}$ & 0 & 0.00018 & $2.02 \cdot 10^{-15}$ & 0 & 0.00018 \\
\hline $\mathrm{C}_{4} \mathrm{H}_{10}$ & $1.53 \cdot 10^{-15}$ & 0 & 0.00006 & $1.53 \cdot 10^{-15}$ & 0 & 0.00006 \\
\hline $\mathrm{O}_{2}$ & 0 & 0.1401 & 0.1953 & 0 & 0.1515 & 0.1953 \\
\hline $\mathrm{N}_{2}$ & 0.2751 & 0.8598 & 0.73519 & 0.2751 & 0.8484 & 0.73519 \\
\hline $\mathrm{H}_{2}$ & 0.096 & 0 & 0 & 0.096 & 0 & 0 \\
\hline $\mathrm{H}_{2} \mathrm{O}$ & 0.385 & 0 & 0 & 0.385 & 0 & 0 \\
\hline $\mathrm{CO}_{\mathrm{CO}}$ & 0.048 & 0 & 0 & 0.048 & 0 & 0 \\
\hline
\end{tabular}



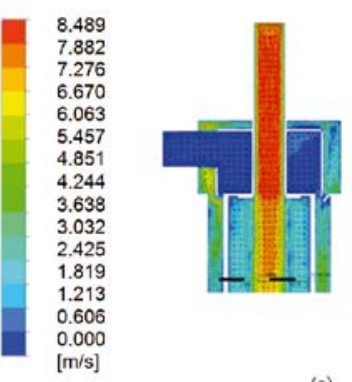

(a)
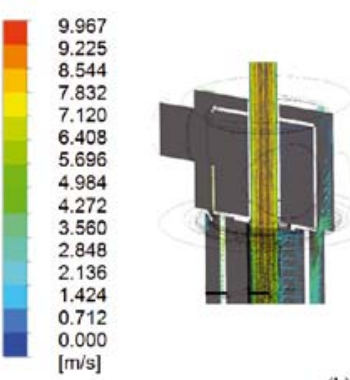

Figure 4. Flow velocity distribution $[\mathrm{m} / \mathrm{s}]$ (a) and flow path (b) inside the burner at the natural gas and air inlets case $\mathrm{I}$ at temperature of $25^{\circ} \mathrm{C}$
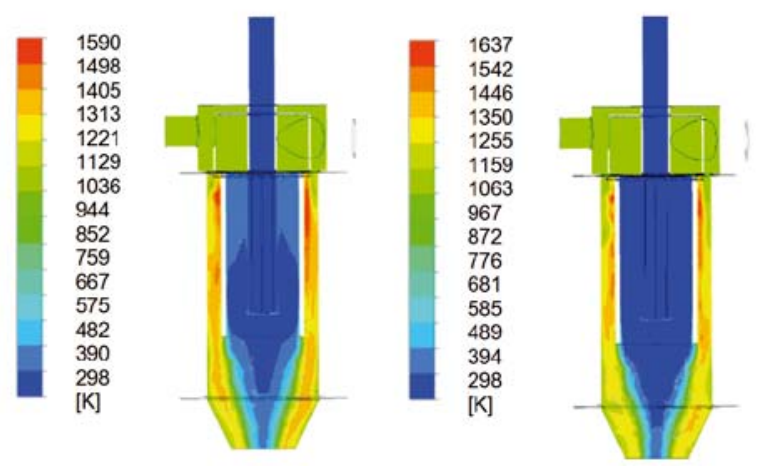

Figure 5. Temperature distributions $[\mathrm{K}]$ over centre plane for case II: (a) 47\% load, (b) 100\% load conditions

reacted inside the burner and a good agreement of the simulated results was achieved in comparison to the experimental data [11]. In general, the developed approach gives good prediction of the species concentrations for both load modes.

The variation in species mole fractions during combustion process inside the new burner design can be seen for chosen species in Figure 8. A major reduction in the methane and oxygen content was observed at the outlet of the burner, while at the same time a considerable amount of carbon dioxide and water vapour was noticed (not presented in Figure 8, but shown in Tables 6 and 7). The CFD results presented in Tables 6 and 7 indicates that major species were completely converted for both $47 \%$ and $100 \%$ loads mode.

Thus, the numerical characterization of the novel burner design was successfully performed as well as areas of high temperature values were identified. Further design optimization based on numerical investigation can be carried out in order to avoid emissions of com-
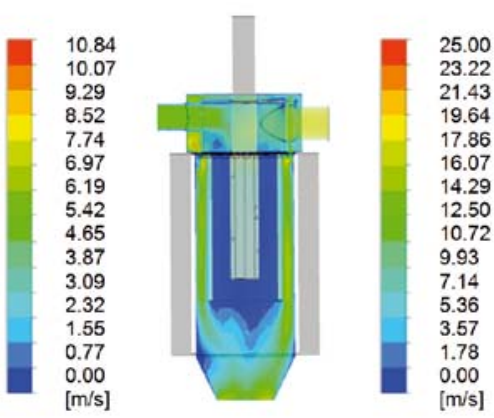

(a)

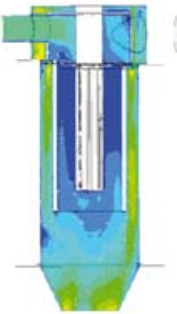

(b)

Figure 6. Velocity distributions $[\mathrm{m} / \mathrm{s}]$ inside the burner, case III at: (a) $47 \%$ load, (b) $100 \%$ load conditions
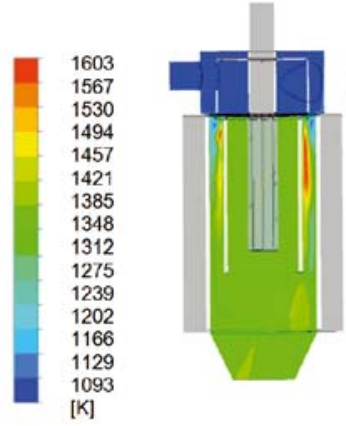

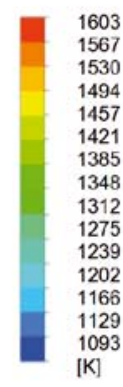

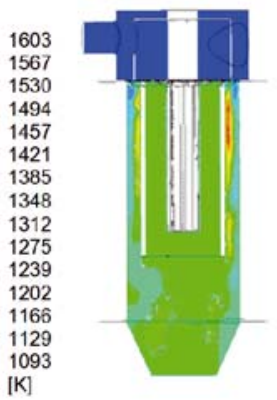

(b)
Figure 7. Temperature distributions $[\mathrm{K}]$ over a centre plane in the burner at, case III at: (a) 47\% load, (b) 100\% load conditions

bustible or toxic gases to the atmosphere as well as to provide a stable flame barrier temperature for chosen operating conditions.

\section{CONCLUSIONS}

This study was conducted to investigate the new burner construction under various operating conditions. The simulation settings were carried out for the anode-off gas and cathode-off gas compositions obtained during the measurements. The accuracy of the simulation results was examined by a comparison with the experimental data. The major conclusions of this study can be drawn as follows:

- the simulations results obtained for the composition of the exhaust gases were in good agreement with the experimental measurements. Thus, the feasibility of the ANSYS Fluent software as a tool useful in predictions of

Table 6. CFD - experimental results comparison for the species mole fractions at the outlet of the burner at $47 \%$ load (case III)

\begin{tabular}{|c|c|c|}
\hline \multirow{2}{*}{ Species } & \multicolumn{2}{|c|}{ Mole fractions [mole/mole] } \\
\cline { 2 - 3 } & \multicolumn{1}{|c|}{ Experiments [11] } & \multicolumn{1}{|c|}{${ }^{-1.266 \cdot 10^{-21}}$} \\
\hline $\mathrm{CH}_{4}$ & $8.79 \cdot 10^{-15}$ & $4.650 \cdot 10^{-28}$ \\
\hline $\mathrm{C}_{2} \mathrm{H}_{6}$ & $4.69 \cdot 10^{-15}$ & $7.456 \cdot 10^{-33}$ \\
\hline $\mathrm{C}_{3} \mathrm{H}_{8}$ & $3.20 \cdot 10^{-15}$ & $5.647 \cdot 10^{-33}$ \\
\hline $\mathrm{C}_{4} \mathrm{H}_{10}$ & $2.43 \cdot 10^{-15}$ & 0.0876 \\
\hline $\mathrm{O}_{2}$ & 0.0974 & 0.7248 \\
\hline $\mathrm{N}_{2}$ & 0.7500 & $1.996 \cdot 10^{-7}$ \\
\hline $\mathrm{H}_{2}$ & $4.36 \cdot 10^{-8}$ & 0.1246 \\
\hline $\mathrm{H}_{2} \mathrm{O}$ & 0.1014 & $2.268 \cdot 10^{-7}$ \\
\hline $\mathrm{CO}_{\mathrm{CO}}$ & $3.95 \cdot 10^{-8}$ & 0.0627 \\
\hline
\end{tabular}


Table 7. CFD and experimental results comparison for the species mole fractions at the outlet of the burner at $100 \%$ load (case III)

\begin{tabular}{|c|c|c|}
\hline \multirow{2}{*}{ Species } & \multicolumn{2}{|c|}{ Mole fractions [mole/mole] } \\
\cline { 2 - 3 } & \multicolumn{2}{|c|}{ Experiments [11] } \\
\hline $\mathrm{CH}_{4}$ & $8.79 \cdot 10^{-15}$ & $4.864 \cdot 10^{-16}$ \\
\hline $\mathrm{C}_{2} \mathrm{H}_{6}$ & $4.69 \cdot 10^{-15}$ & $1.786 \cdot 10^{-22}$ \\
\hline $\mathrm{C}_{3} \mathrm{H}_{8}$ & $3.20 \cdot 10^{-15}$ & $2.863 \cdot 10^{-27}$ \\
\hline $\mathrm{C}_{4} \mathrm{H}_{10}$ & $2.43 \cdot 10^{-15}$ & $2.169 \cdot 10^{-27}$ \\
\hline $\mathrm{O}_{2}$ & 0.0974 & 0.1035 \\
\hline $\mathrm{N}_{2}$ & 0.7500 & 0.7332 \\
\hline $\mathrm{H}_{2}$ & $4.36 \cdot 10^{-8}$ & $1.103 \cdot 10^{-7}$ \\
\hline $\mathrm{H}_{2} \mathrm{O}$ & 0.1014 & 0.1091 \\
\hline $\mathrm{CO}$ & $3.95 \cdot 10^{-8}$ & $1.171 \cdot 10^{-7}$ \\
\hline $\mathrm{CO}_{2}$ & 0.0510 & 0.0541 \\
\hline Temperature $\left[{ }^{\circ} \mathrm{C}\right]$ & 1022.56 & 1056.66 \\
\hline
\end{tabular}

the combustion process inside the burner was confirmed and the simulation procedure was validated,

- during the start-up operation (case I) the temperature stabilizes at a value of around $873[\mathrm{~K}]$, while during the normal operation mode the average working temperature was equal to $1116[\mathrm{~K}]$. Air was required to maintain a stable flame barrier temperature at that level for cooling when additional fuel was introduced into the burner.

Taking into consideration the numerical results obtained for the first burner prototype it can be concluded that this study provides an useful starting point for further development of an automated burner control system design, which will allow efficient adaptation to working conditions of the CHP systems based on the SOFCs.
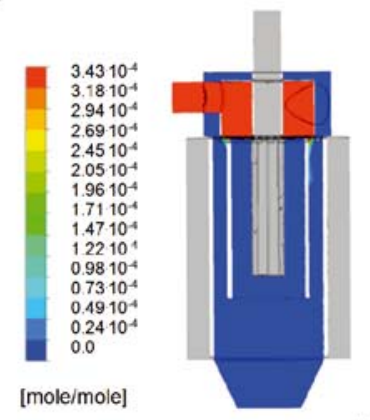

(a)
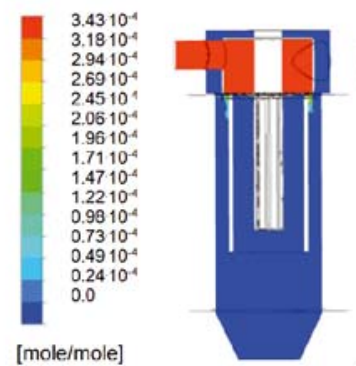

(b)

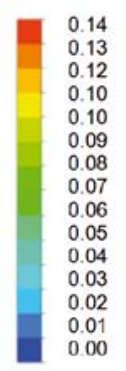

[mole/mole]

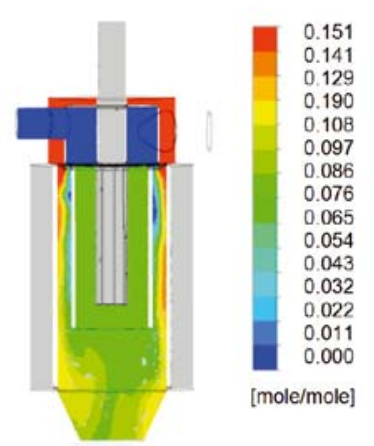

(a)

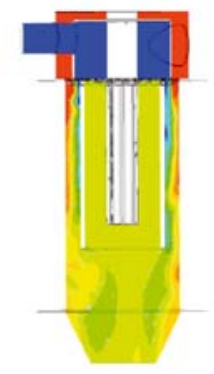

(b)

Figure 8. Mole fraction distributions of methane (i) and oxygen (ii) at: (a) $47 \%$ load, (b) $100 \%$ load conditions for case III

\section{NOMENCLATURE}

a $\quad-$ absorption coefficient, $\left[\mathrm{dm}^{3} \mathrm{~mol}^{-1} \mathrm{~cm}^{-1}\right]$

$c_{\mathrm{p}} \quad-$ average specific heat, $\left[\mathrm{Jkg}^{-1} \mathrm{~K}^{-1}\right]$

$\mathrm{C}_{1 e}$ - constant, [-]

$\mathrm{C}_{2 e}-$ constant, [-] f - mixture fraction in the non-premixed model, $\left[\right.$ molemole $^{-1}$ ]

$\mathrm{g}_{\mathrm{i}} \quad-$ gravitational force $\left[\mathrm{ms}^{-2}\right]$

$\mathrm{G}_{\mathrm{k}} \quad$ - generation of turbulence kinetic energy, $\left[\mathrm{m}^{2} \mathrm{~s}^{-2}\right]$

$\mathrm{f}_{\mathrm{l}} \quad-$ mass fraction, [molemole ${ }^{-1}$ ]

$\mathrm{F}_{\mathrm{i}} \quad-$ mass force, $[\mathrm{N}]$

$\mathrm{H}$ - enthalpy, $\left[\mathrm{Jkg}^{-1}\right]$

$\mathrm{I}(\overrightarrow{\mathrm{r}}, \overrightarrow{\mathrm{s}})$ - total radiation intensity, $\left[\mathrm{Wsr}^{-1}\right]$

$\mathrm{k} \quad-$ turbulence kinetic energy, $\left[\mathrm{m}^{2} \mathrm{~s}^{-2}\right]$

$\mathrm{k}_{\mathrm{t}} \quad-$ thermal conductivity, $\left[\mathrm{Wm}^{-1} \mathrm{~K}^{-1}\right.$ ]

$\mathrm{n}-$ refractive index, [-]

$\mathrm{p}$ - pressure, $[\mathrm{Pa}]$

$\vec{r} \quad-$ position vector, $[-]$

$\overrightarrow{\mathrm{s}}-$ direction vector, [-]

$\overrightarrow{\mathrm{s}}$ - scattering direction vector, [-]

$\mathrm{S}_{\mathrm{h}} \quad$ - heat source term, $\left[\mathrm{Wm}^{-2}\right]$

$\mathrm{S}_{\mathrm{i}} \quad-$ mass source term, $\left[\mathrm{kgm}^{-2} \mathrm{~s}^{-1}\right]$

$\mathrm{T}$ - local temperature, $[\mathrm{K}]$

$\mathrm{u}_{\mathrm{i}} \quad-$ velocity vector, $\left[\mathrm{ms}^{-1}\right]$

$\mathrm{u}_{\mathrm{j}} \quad-$ velocity vector, $\left[\mathrm{ms}^{-1}\right]$

$\overrightarrow{\mathrm{u}} \quad-$ velocity vector, $\left[\mathrm{ms}^{-1}\right]$

$\mathrm{x}_{\mathrm{i}}, \mathrm{x}_{\mathrm{j}}$ - direction vector, [-]

$\mathrm{Z}_{\mathrm{i}} \quad$ - elemental mass fraction for element $i,\left[\mathrm{kgkg}^{-1}\right]$

$\mathrm{Z}_{\mathrm{i}, \mathrm{Ox}}$ - oxidant mass fraction for element, $i,\left[\mathrm{kgkg}^{-1}\right]$

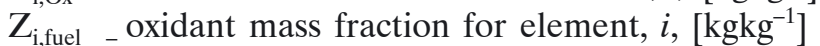

\section{Greek symbols}

$\varepsilon \quad-$ dissipation turbulence kinetic energy, $\left[\mathrm{m}^{2} \mathrm{~s}^{-3}\right]$

$\mu \quad-$ viscosity, [Pas]

$\mu_{\mathrm{t}} \quad-$ turbulent viscosity, [Pas]

@ - density, $\left[\mathrm{kgm}^{-3}\right]$

$\sigma \quad-$ Stefan-Boltzmann constant, $\left[\mathrm{Wm}^{-2} \mathrm{~K}^{-4}\right]$

$\sigma_{\varepsilon} \quad-$ turbulent Prandtl number for $\varepsilon,[-]$

$\sigma_{\kappa} \quad$ - turbulent Prandtl number for k, [-]

$\sigma_{s} \quad-$ scattering coefficient, $\left[\mathrm{cm}^{-1}\right]$

$\tau_{\mathrm{ij}} \quad-$ stress tensor, $[\mathrm{Pa}]$

$\lambda \quad$ - wavelength, $[\mathrm{Hz}]$

$\varphi \quad-$ phase function, [-]

$\Omega^{\prime} \quad-$ solid angle, $[\mathrm{sr}]$

\section{Subscripts}

ox - oxidizer stream inlet

fuel - fuel stream inlet

\section{Abbreviation list}

CFD - Computational Fluid Dynamics

CHP - Combined Heat and Power system

DO - Discrete Ordinates method

k-w $\quad-$ Turbulence model 


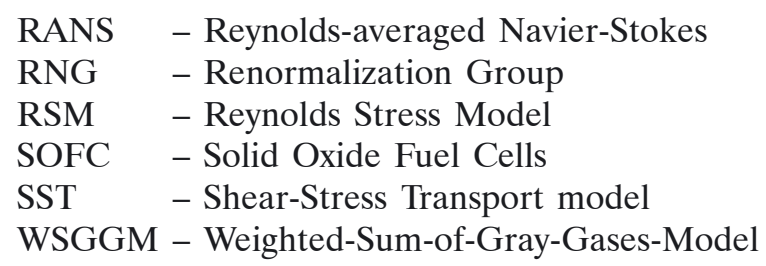

\section{ACKNOWLEDGEMENTS}

The research programme leading to these results received funding from the European Union's Seventh Framework Programme (FP7/2007-2013) for the Fuel Cells and Hydrogen Joint Undertaking (FCH JU) under grant agreement $\mathrm{n}^{\circ}$ [621213]. Information contained in the paper reflects only view of the authors. The FCH $\mathrm{JU}$ and the Union are not liable for any use that may be made of the information contained therein. The work was also financed from the Polish research funds awarded for the project No. 3126/7.PR/2014/2 of international cooperation within STAGE-SOFC in years 2014-2017.

\section{LITERATURE CITED}

1. Zhang, X., Chan, S.H., Li, G., Ho, H.K., Li, J. \& Feng, Z. (2010). A review of integration strategies for solid oxide fuel cells, J. of Power Sources, 195, 685-702. DOI: 10.1016/j. jpowsour.2009.07.045.

2. Chan, S.H., Low, C.F. \& Ding, O.L. (2002). Energy and exergy analysis of simple solid oxide fuel cell power systems, $J$. of Power Sources, 103, 188-200. DOI: S0378-7753(01)00842-4.

3. Fontell, E., Jussila, M., Hansen, J.B., Palsson, J., Kivisaari, T. \& Nielsen, J.U. (2005). Wartsila-Haldor Topsoe, SOFC test system, abstract presented in SOFC-I, Quebec, Canada, 15-20 May 2005.

4. Hong, W.T., Yen, T.H., Huang, Ch.N., Tan, H.I. \& Chao, Y. (2013). Design and development of major balance of plant components in solid oxide fuel cell system, International J. of Energy and Environment, 4 (1), 73-84. ISSN 2076-2895.

5. Yen, T.H., Hong, W.T., Huang, W.P., Tsai, Y.Ch., Wang, H.Y., Huang, Ch.N. \& Lee, Ch.H. (2010). Experimental investigation of $1 \mathrm{~kW}$ solid oxide fuel cell system with a natural gas reformer and an exhaust gas burner, J. of Power Sources, 195, 1454-1462. DOI: 10.1016/j.jpowsour.2009.09.021.

6. Yu, S., Hong, D., Lee, Y., Lee, S. \& Ahn, K. (2010). Development of a catalytic combustor for a stationary fuel cell power generation system, Renewable Energy, 35, 1083-1090. DOI: 10.1016/j.renenen.2009.10.015.

7. Zadghaffari, R., Moghaddas, J.S. \& Rahimiahar, R. (2012). Numerical investigation of a burner configuration to minimize pollutant emissions, APCBEE Procedia, 3, 177-181. DOI: $10.1016 /$ j.apcbee.2012.06.066.

8. Frenzel, I., Loukou, A. \& Trimis, D. (2011). An innovative burner concept for the conversion of anode off gas from high temperature fuel cell systems, $11^{\text {th }}$ Conference on Energy for a Clean Environment, 5-8 July 2011, 1-13.

9. Reis, L.C.B.S., Carvalho, J.A., Nascimento, M.A.R., Rodrigues, L.O., Dias, F.L.G. \& Sobrinho, P.M. (2014). Numerical modeling of flow through an industrial orifice, Applied Thermal Engineering, 67, 201-213. DOI: 10.1016/j.applthermaleng.2014.02.036.

10. Fu, J., Tang, Y., Li, L., Ma, Y., Chen, W. \& Li, H. (2016). Four kinds of the two-equation turbulence model's research on flow field simulation performance of DPF's porous media and swirl type regeneration burner, Applied Thermal Engineering, 93, 397-404. DOI: 10.1016/j.applthermaleng.2015.09.116.

11. Internal report from sunfire - technical coordinator of the STAGE-SOFC project, 2015. 